\title{
Listening Strategies of L2 Learners With Varied Test Tasks
}

\section{Anna Ching-Shyang Chang}

This article investigates the strategies that EFL students used and how they adjusted these strategies in response to various listening test tasks. The test tasks involved four forms of listening support: previewing questions, repeated input, background information preparation, and vocabulary instruction. Twenty-two participants were enlisted and interviewed from a sample of 160 business major students based on their listening anxiety levels. Overall results showed that various listening tasks influenced test takers' listening strategies by varying degrees, with previewing test questions tending to have a greater effect on strategy use than other types of support. This study also found that both anxious and non-anxious students knew how to use the available information before taking a test; however, while doing the task, many students lacked competence to employ the strategies they intended to use. Finally, the article discusses some subtle problems reported by the interviewees and also provides scope for future research.

Cet article porte sur les stratégies qu'emploient les élèves d'ALE et les modifications qu'ils y apportent en réaction à diverses tâches de tests d'écoute. Ces tâches impliquaient quatre formes d'appui à l'écoute: une prélecture des questions, la répétition de la matière, une préparation grâce aux renseignements généraux et de l'information portant sur le vocabulaire. D'un échantillon de 160 étudiants se spécialisant en affaires, 22 ont été retenus et interviewés en fonction de leur niveau d'anxiété à l'écoute. Les résultats globaux indiquent que diverses tâches à l'écoute ont influencé les stratégies d'écoute des participants à différents degrés. Parmi les formes d'appui, c'est la prélecture des questions qui avait le plus d'effet sur l'emploi des stratégies. L'étude démontre également que tant les étudiants anxieux que ceux qui ne sont pas anxieux savent se servir de l'information disponible avant de passer un examen. Toutefois, en accomplissant une tâche donnée, plusieurs étudiants n'avaient pas les habiletés requises pour mettre en oeuvre les stratégies qu'ils voulaient employer. L'article conclut en évoquant quelques problèmes mineurs rapportés par les participants et en offrant des pistes d'avenir pour la recherche.

\section{Introduction}

This study investigates strategies L2 learners use to comprehend spoken input under varied forms of listening support and then further examines 
whether learners with varying levels of listening anxiety would use different strategies to complete test tasks. The study aims to establish if L2 learners are able to make use of information provided for them and to determine whether strategy instruction is necessary when listening support is provided. What can be done to help anxious learners if a gap is found between their competence and that of less anxious students?

The motivation for the current study is the fact that in a foreign language environment, students typically learn English through formal classroom instruction and have limited exposure to the language outside formal study. In such circumstances, their ability to comprehend spoken English may be limited (Kim, 2006; Huang, 2005), making high-stakes listening comprehension tests particularly stressful. To add to this problem, listening in a test situation usually requires precise comprehension and precludes opportunities to clarify or negotiate with the speaker (Buck, 2001). Therefore, Underwood (1989) suggests that before a listening task begins, students should be "tuned in" so that they know what to expect to hear. This can be done through various types of preparatory work such as pre-listening activities or providing forms of listening support. This kind of preparatory work is assumed to help ease students' processing load and so improve comprehension. However, despite this assumption, the effectiveness of listening support is still variable (Berne, 1995; Chang, 2004, 2005a; Chang \& Read, 2006; Elkhafaifi, 2005b). In order to understand the factors that contribute to the inconclusive findings about listening support, this research looks at two important factors that may interact closely with the characteristics of a test task: strategies used by learners to comprehend spoken input and learners' levels of listening anxiety.

\section{The Use of Listening Support in Listening Comprehension Tests}

Because listening is not easy for foreign-language learners in general, providing test-takers with some form of support before or while listening may have an effect on their use of strategy. The most popular kinds of listening support are previewing questions and repeated input, usually embedded in a test design. Opinion is divided on the effectiveness of previewing questions. Some researchers consider this support helpful because it may provide testtakers with extra information (Buck, 1991; Cohen, 1984; Shohamy \& Inbar, 1991; Sherman, 1997; Chang \& Read, 2006, 2007), whereas others regard it as interference because it may preoccupy listeners and interrupt their thinking (Weir, 1993; Ur, 1984). In studies by Buck and Chang and Read, students reported that previewing questions helped their comprehension because the questions revealed the content of the story. In addition, after they read the questions, they listened specifically for answers to the questions, implying that previewing questions affected their listening strategy. 
Another popular form of listening support is repeated input. Repetition has been used as an important strategy in second-language learning and teaching, and its effects_-according to Hatch (1983)—are to afford greater processing time and to make syntactic forms clearer. Many listening comprehension studies and tests involve a repetition strategy to make information clearer and more comprehensible. Such studies have typically shown positive effects on comprehension (Cervantes \& Gainer, 1992; Chaudron, 1983; Chiang \& Dunkel, 1992; Chang, 1999; Chang \& Read, 2007). In a survey of Taiwanese college students, Teng (1998) found that $53 \%$ of college students asked to listen at least three times, and $47 \%$ twice. Given this high percentage of students requesting repeated input in a foreign-language environment, its importance and its effects deserve further investigation. From the findings mentioned above, repetition appears to be effective in general, although not for all levels of learners (Chang; Chang \& Read.

Other forms of listening support can be offered through pre-listening activities such as language and topic preparation. However, the effect of vocabulary support on facilitating listening is less clear than for other forms of support (Berne, 1995; Chang, 2005a; Chang \& Read, 2006). Both Berne and Chang and Read speculate that pre-teaching vocabulary before listening might negatively affect test-takers' strategies because the listeners may focus on local cues and neglect to pay attention to the global understanding of the text.

There is little research on the effect that prior general background knowledge has on listening comprehension test results; however, the effect of specific religious and cultural background knowledge on listening comprehension has been shown to be positive (Markham \& Latham, 1987; Chiang \& Dunkel, 1992; Teng, 1993). The results of other studies on the relationship between listening comprehension and prior knowledge of specific domains or topics are mixed (Jensen \& Hansen, 1995; Chang \& Read, 2006). The notion that background knowledge activation may enhance listening comprehension is based on several studies of reading comprehension. These have shown that pre-teaching background knowledge of the topic helped readers gain a global picture of the input (Hudson, 1982; Taglieber, Johnson, \& Yarbrough, 1988; Hsieh, 1999), and Hudson even found that the effect of background knowledge may override learners' language proficiency. However, more recently Chang (2006) studied the thresholds of the effect of background knowledge on college students' listening comprehension by means of graded audio-readers. She found that listening competence was essential for them to comprehend the details of stories. Topical knowledge is only supplementary. For low-level language learners, the effect of topical knowledge support can be limited.

The four forms of listening support reviewed have varying effects on learners' comprehension. Leaving aside repeated input, which has been 
found to be helpful in general, the effectiveness of the other three forms of listening support were inconclusive. For this study, I explore what strategies are used by learners to complete the test task. I then examine the relationship between strategy use and listening comprehension.

\section{Listening Strategies in Listening Comprehension}

The use of listening strategy has been studied extensively over the past two decades, particularly focusing on identifying the strategies used by higherversus lower-proficiency learners in terms of quality and quantity, cues and sequences, and strategy instruction. Research in this area has shown that: (a) more advanced listeners use increasingly varied strategies than less advanced listeners (Murphy, 1987; Chin \& Li, 1998; Goh, 2002; Chao \& Chin, 2005); (b) the better a listener's proficiency, the more metacognitive strategies he or she uses (Vandergrift, 1997a, 1997b); (c) when encountering more difficult texts, listeners tend to use bottom-up strategies (Vogely, 1995; Bacon, 1992); (d) successful learners can use both linguistic and background knowledge at the same time, although poor learners may overrely on one kind of knowledge (Rost \& Ross, 1991; Vandergrift, 1997b); (e) native speakers of English and advanced learners of English mainly use semantic cues, whereas intermediate L2 learners rely more on syntactic cues (Conrad, 1985); and (f) in relation to strategy instruction, no immediate effect on enhancing listening comprehension was found in most studies (Thompson \& Rubin, 1996; Vandergrift, 1999; Field, 1998; Mendelsohn, 1994, 1995) except for Goh and Taib (2006), and higher listening proficiency was assumed to be needed to make the instruction effective.

The research mentioned above shows that a good deal of attention has been given to the relationship between strategy use and language proficien$c y$, and the results have consistently shown that strategy use is associated with learners' language competence. According to Bachman and Palmer (1996), language competence itself involves "language knowledge and strategic competence," (p. 62), suggesting that the better the language competence, the better the language knowledge and strategic competence.

In addition to listening or language competence, many other factors may affect learners' choices of strategy use. In a small-scale, in-depth study, Chang (2005b) interviewed seven Chinese students studying overseas. Her study showed that choice of listening strategy and listening anxiety were interrelated, with listening strategies greatly influencing listening anxiety. Other variables came into play such as familiarity with the topic, question type, amount of preparation time, whether previewing questions was allowed, and the type of input, all of which affected students' listening strategy and anxiety levels. Therefore, listening anxiety seems to be another variable that has not received enough attention. 


\section{Listening Anxiety in Listening Comprehension}

As with using listening strategy, some studies on listening anxiety have found an association with language competence (Aneiro, 1989; Vogely, 1995; Chen \& Chang, 2004; Elkhafaifi, 2005a; Liu, 2006; Mills, Pajares, \& Herron, 2006; Chang, 2008). In general, language competence is undeniably an essential factor that affects anxiety; however, in a test situation, test task characteristics are also important variables that affect test-takers' performance (Bachman \& Palmer, 1996). The characteristics of test tasks include previewing questions, multiple listening, sufficient background or linguistic knowledge, and being familiar with the test format. All these variables affect learners' listening anxiety to a certain extent (Chang, 2005b).

In the above sections, I look at varying forms of listening support, the types of strategies most frequently mentioned in the literature, and the factors affecting listening anxiety. I find, however, that the strategies used by learners who experience varying levels of listening anxiety have not been fully explored. This research considers the following questions.

1. What strategies were employed by L2 learners for various test tasks? Did varied test tasks affect L2 learners' choice of strategy use?

2. Did L2 learners experiencing varying levels of listening anxiety use varied strategies for varied test tasks? If the answer is Yes, what were the differences and what can be done to close the gap between the two groups?

\section{The Study}

\section{The Participants}

The participants recruited for this study were 22 business major students at a college in Taiwan with an average age of 18 years. Their listening proficiency level was between beginning and low intermediate based on a TOEIC test. Eighteeen students were female and four were male. The participants were selected from the high- and low-scoring quartiles of a larger group of 160 business majors who completed a listening anxiety questionnaire (described below). Twelve participants were from the high-scoring quartile (highly anxious) and 10 were from the low-scoring quartile (less anxious); for the remainder of this article I term them anxious and non-anxious students.

\section{The Design of the Study}

Four forms of listening test support were designed to elicit the types of strategies learners used. These were previewing questions (PQ), repeated input (RI), topic preparation (TP), and vocabulary instruction (VI). The PQ group previewed the test questions before taking the test, and this form of support served as the baseline across the groups. The RI group listened to the texts three times, following Sherman's (1997) sandwich model whereby par- 
Table 1

The Four Forms of Listening Support

\begin{tabular}{|c|c|c|c|}
\hline $\begin{array}{c}\text { Previewing } \\
\text { Questions (PQ) }\end{array}$ & $\begin{array}{l}\text { Repeated } \\
\text { Input }(R I)\end{array}$ & $\begin{array}{c}\text { Topic Preparation } \\
(T P)\end{array}$ & $\begin{array}{c}\text { Vocabulary } \\
\text { Instruction (VI) }\end{array}$ \\
\hline $\begin{array}{c}\text { No preparation but } \\
\text { listen to textbook } \\
\text { CD } \\
\downarrow \\
\text { Preview questions } \\
\downarrow \\
\text { Listen once }\end{array}$ & $\begin{array}{c}\text { No preparation but } \\
\text { listen to textbook } \\
\text { CD } \\
\downarrow \\
\text { Listen once } \\
\downarrow \\
\text { Preview questions } \\
\downarrow \\
\text { Listen twice }\end{array}$ & $\begin{array}{c}\text { Read topic-related } \\
\text { materials } \\
\downarrow \\
\text { topic discussions } \\
\downarrow \\
\text { Preview questions } \\
\downarrow \\
\text { Listen once }\end{array}$ & $\begin{array}{c}\text { Study topic-related } \\
\text { vocabulary and } \\
\text { phrases } \\
\downarrow \\
\text { Pronunciation } \\
\text { practice } \\
\text { and } \\
\text { topic-related } \\
\text { dialogue } \\
\text { warm-up } \\
\downarrow \\
\text { Preview questions } \\
\downarrow \\
\text { Listen once }\end{array}$ \\
\hline
\end{tabular}

ticipants listened to a passage once, previewed the questions, and then listened twice more. The TP group first studied two written texts related to the general topics of the listening texts, followed by a discussion on the two topics led by the teacher. The VI group received two word lists to study first and then participated in some warm-up activities (See Table 1)

\section{The Instruments}

The first instrument used in this study was a listening strategy questionnaire examining the strategies most frequently used in a general test situation. The aim was to understand whether varied strategies were employed for varied tasks. The second instrument was a questionnaire on listening anxiety developed to select targeted participants. Finally, a listening comprehension test with four forms of listening support was administered to elicit students' responses on their use of strategy. Each instrument is described in further detail below.

The Listening Strategy Questionnaire

To examine the effect of listening support on learners' strategy use, listening strategies used in general test situations were investigated first. The listening strategy questionnaire contained 35 items with five subcategories: strategies before taking a test (SBT), strategies while taking a test (SWT), strategies after taking a test, strategies for listening to audiotapes, and strategies for watching video or TV programs. As I originally developed the questionnaire to investigate what strategies EFL learners would use for taking a listening test and for practicing English listening outside the class, I present only the 
strategies before and during a test (SBT \& SWT, for results see Appendixes A and B). Each statement was rated on a five-point scale: always, usually, often, sometimes, and never to reflect frequency of use. One example from the SBT is: Before taking an English listening test, I think about the purpose of the test and then choose strategies to manage it. An example from the SWT is: I focus on the message (main ideas and key words), not every word (see Appendix C).

The Listening Anxiety Questionnaire

The questionnaire was developed by Chang (see Chang, 2008, for the whole questionnaire) to capture Taiwanese college students' listening anxiety levels. It contained 22 items dealing with listening anxiety in a classroom context and 11 items in a test situation. As with the strategy questionnaire, each item consisted of a statement to be rated on a five-point scale, for example, Listening to someone speaking fast makes me nervous (Item 16).

The Listening Comprehension Test

The listening input test consisted of two short scripted monologues containing 260 and 369 words and read at 164 and 157 words per minute respectively. The first, on the topic of good health, was taken from a textbook for EFL learners (Foley, 1994), whereas the second, describing social customs in New Zealand, was written by the researcher. For each text, 15 multiple-choice items (in English) were created, making a total of 30 items for the test. The questions involved both global and specific information.

Topic Material

Two reading texts written in Chinese were prepared for the TP group. The first reading text on good health contained about 300 words, and the second text on New Zealand had about 500 words. The two texts included only general information about the test topics. No specific details were provided that might have helped the participants to answer particular questions on the test.

Vocabulary Study Lists

For the VI group, two word lists were prepared. The first list contained 23 words related to health, and the second list had 25 words related to New Zealand social customs. Each word was accompanied by its Chinese equivalent. Only one third of the listed words were unfamiliar to students according to student self-reporting conducted during the pilot.

\section{The Procedure}

The PQ and RI groups were not involved in any preparatory activity for the test, and during their first hour of class, these two groups listened to instructional material from the CD-ROM that accompanied the course textbook Impact Listening 3 (Harsch \& Wolfe-Quintero, 2001). The material was not 
relevant to the test content; it was simply a review of lessons that students had previously studied.

The TP group studied two written texts related to topics of the listening texts. They spent the first 25 minutes of their preparation time reading the material, followed by 25 minutes of discussion led by the teacher. The VI group first studied the vocabulary lists on their own for 25 minutes, followed by 15 minutes of the teacher helping students pronounce each word and pointing out how the meaning of some words varied according to their grammatical context. During the last 10 minutes of class, these students listened to eight short pre-recorded dialogues, which gave them some practice in hearing what a number of the target words sounded like in connected speech.

The listening tests were carried out in an audiovisual language classroom where each student had a separate seat, a monitor, and a set of headphones. The test tapes were played through the language laboratory console, and the students could hear the recorded listening passages either from the room speakers or from their headphones depending on their personal preference. To randomize assignment of the four listening formats to students, the college scheduled the four classes on two separate days without input from me. Two classes were on Monday, the PQ group in the morning and the RI group in the afternoon, and two on Friday, the TP group in the morning and the VI group in the afternoon. The schedule was designed with two issues in mind: to allow interviews to be conducted immediately after the listening comprehension test and to minimize opportunities for students to share information.

The Post-Listening Interviews

Post-task interviews were conducted mainly in Chinese immediately after the listening tasks in order to elicit information about the particular strategies students used to complete the listening task. Each interview lasted about 40 minutes with prepared questions (see Appendix D).

\section{Data Analysis}

The main focus of the current study is the influence of listening task format on strategy use. Therefore, the interviewees' overall listening performance is reported only briefly. The interview data were analyzed manually as the participants responded directly to the prepared questions. Their responses in relation to listening strategy use were analyzed in terms of the various types of listening support and anxiety levels. The purpose was to find out how varied listening support affected students' decisions in strategy use and whether anxious as compared to non-anxious students used varying strategies when given varied types of listening support. 
Table 2

Interviewees' Listening Comprehension Test Scores (in Percentages)

in Each Subgroup Given a Different Level of Listening Anxiety

\begin{tabular}{lllll}
\hline Listening & $\begin{array}{l}\text { Preview } \\
\text { questions }\end{array}$ & $\begin{array}{l}\text { Repeated } \\
\text { input }\end{array}$ & Topical & Vocabulary \\
\hline Anxious & Amy (37) & George (53) & Rick (47) & Lily (53) \\
& Betty (57) & Helen (57) & Sally (67) & Mary (47) \\
& Christine (43) & Isabella (47) & Tracy (63) & Nathan (67) \\
Less anxious & Debby (40) & Jill (93) & Vivian (67) & Pam (47) \\
& Ellen (60) & Kate (80) & Wilbur (40) & Patricia (73) \\
& Frank (57) & & Wilson (90) & \\
\hline
\end{tabular}

${ }^{1}$ The numerical indexes in parentheses are the listening comprehension test scores (in \%).

\section{Results and Discussion}

\section{The Listening Comprehension Test Result}

The mean of the listening comprehension test for the whole sample (160 participants) was 17.11 out of 30 , which is equal to $57 \%$. The reliability coefficient (Cronbach's $\alpha$ ) was .70, a moderate level. However, it can be considered satisfactory for a teacher-made test of just 30 multiple-choice items. The 22 interviewees' listening comprehension test results (pseudonyms are used) are presented in Table 2. Overall, it can be seen that less anxious students did a little better than anxious ones and that three students, Jill and Kate in the RI group and Wilson in the TP group, did particularly well. The information presented here is for reference only and is not the main focus of the study.

The Effect of Varied Forms of Listening Support on Strategy Use

In this section, I first look at how varying test tasks affected the strategies used by learners in each group. The concern here is not the quantitative difference, but the depth of the students' interaction with the listening support before and during listening to oral input. Whether strategy use was affected by varying types of listening support or whether students simply adopted the same strategies used in a general test situation is examined.

Previewing Questions

A total of 10 strategies had previously been reported by interviewees given a preview of the questions (see Table 3). Compared with the strategies used in the general test situation (see Appendix B), where no listening support was provided, only four strategies were stimulated when test questions were previewed. These were: (7) matching the words found in the test questions with those heard in the recordings; (8) trying to find content clues after 
Table 3

Strategies Used by the PQ Group

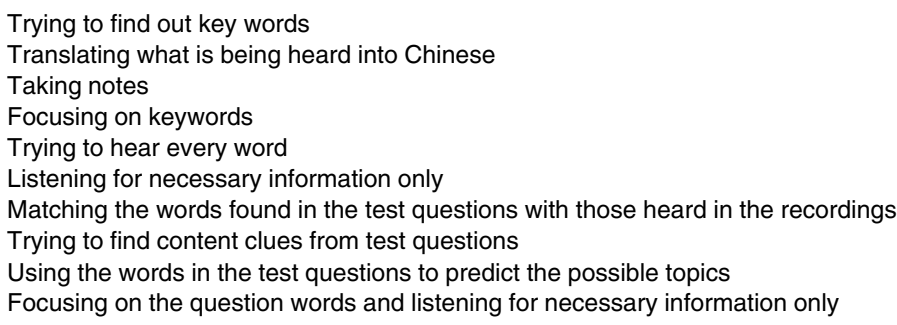

*Strategy stimulated by the support.

reading the test questions; (9) using the words in the test questions to predict the possible topics; and (10) focusing on the question words and listening for necessary information only.

At least one student in each group reported using strategy (7), matching words or phrases heard in the recordings with those found in the test questions. How did this strategy affect test-taker task performance? This strategy was used while listening to the recordings. If words used in test items match the words spoken in the listening passages, this is called lexical overlap (Buck, 2001, p. 153). According to Buck, "lexical overlap between the correct option and the text, especially the necessary information, is the best predictor of easy items. Similarly, lexical overlap between the text and the incorrect options is the best predictor of difficult items" (p. 153). Options such as all the above or none of the above can cause great difficulty in multiple-choice questions as a result of this. It is apparent that using lexical overlap is not only an ineffective strategy, but also risky to use in a listening test as this strategy must rely heavily on linguistic cues, and it also draws attention away from ongoing interpretation of the text. Thus students will not be able to grasp the gist of the discourse, and their comprehension will be incomplete. The use of strategies (8) and (9), finding content clues, and predicting the possible topics, indicated that before listening, the participants tried to obtain a global picture of the listening passages by using available information to predict possible content. When they listened, some students became selective and focused only on the relevant information, which may have helped them reduce linguistic and information loads.

The above analysis shows that previewing questions can have both positive and negative effects on listeners' strategy use. On the positive side, previewing questions may reveal content clues and thus encourage listeners to predict possible information rather than plunging into listening texts without any preparation. Furthermore, for more advanced listening profi- 
Table 4

Strategies Used by the RI Group

\begin{tabular}{cl}
\hline 1 & Translating what is heard into Chinese \\
2 & Guessing the content based on the understood words \\
3 & Trying to find topic clues from test questions \\
4 & $\begin{array}{l}\text { Choosing the answers by matching words in the test questions and hearing } \\
\text { listening for keywords }\end{array}$ \\
${ }^{*} 5$ & $\begin{array}{l}\text { Revising comprehension by hearing three times } \\
6\end{array}$ \\
7 & Creating a picture of what is being heard \\
8 & Linking what is heard with one's experience \\
9 & Tell oneself not to be nervous
\end{tabular}

${ }^{*}$ Strategy stimulated by the support.

ciency (LP) learners, previewing questions may encourage them to be more selective rather than listening for everything. The negative aspect is that previewing questions may encourage some learners to approach the discourse by focusing on linguistic cues and ignore the main focus.

\section{Repeated Input}

Nine strategies were reported by interviewees as given repeated input, but many of these were also reported in the general listening test (see Table 4). In interviews, students reported relatively little about how repeated input affected their strategy use. An explanation for this could be that repeated input has been used often in classroom listening tests, so the test-takers did not consider it a form of support. However, repeated listening may influence both cognitive and affective strategies. From a cognitive perspective, students reported that they kept revising their comprehension by listening three times; as an affective strategy, they told themselves not to be nervous because they knew they had three chances to listen to the input.

Topical Preparation

With regard to the effect of background knowledge on listeners' strategy use, the students in the TP group reported that because they knew the topics and some of the background information, they paid direct attention to details. This implied that they used a bottom-up strategy to answer questions. However, the students did not report how background knowledge affected their strategy use, and their strategies were very different from those of other groups. They neither guessed content nor predicted topics because they had a global picture of the incoming oral input. Therefore, some directed their attention to self-management-not to be nervous, not to think about the mark, and pay full attention-and some to selective listening. From this point of view, learners with topical knowledge may feel that the task is less 
Table 5

Strategies Used by the TP Group

\begin{tabular}{|c|c|}
\hline 1 & Guessing the content based on the understood parts \\
\hline 2 & $\begin{array}{l}\text { Choosing the answers by matching words in the test questions and } \\
\text { hearing/listening for keywords }\end{array}$ \\
\hline *3 & Listening for detailed information because the topics were known \\
\hline 4 & Focusing on the question words in the test questions \\
\hline 5 & Listening for relevant information to the questions only \\
\hline 6 & Avoid thinking about the input in Chinese \\
\hline 7 & Telling oneself not to be nervous \\
\hline 8 & Telling oneself not to think about the mark \\
\hline 9 & Paying full attention to the test \\
\hline
\end{tabular}

${ }^{*}$ Strategy stimulated by the support.

demanding so their attention can be directed to the details. Because some of the questions required detailed information, perhaps this was why the students in this group achieved a higher score than other groups. Although nine strategies were mentioned by interviewees, only four seemed to be affected by listening support (see Table 5) Three out of the four were actually mentioned by the previous group. Therefore, it is apparent that only (9) listening for detailed information because the topics were known was truly influenced by topical background information.

Vocabulary instruction

In respect to the effect of vocabulary instruction on strategy use, five strategies were reported (see Table 6). However, only two seemed to be influenced by vocabulary support, strategies (2) and (5). According to the students, they could predict the topics or key words by looking at the words on the lists and test questions. Regardless of how accurate their predictions were, their listening test performances were not satisfactory. Nevertheless, this shows that providing vocabulary activated the metacognitive strategy of predicting what the topics might be according to the words given.

Table 6

Strategies Used by the VI Group

\begin{tabular}{|c|c|}
\hline 1 & Guessing the content based on the understood words \\
\hline *2 & Predicting the topics through test questions and vocabulary lists \\
\hline 3 & $\begin{array}{l}\text { Choosing the answers by matching words in the test questions and } \\
\text { hearing/listening for keywords }\end{array}$ \\
\hline 4 & Listening for topics first, then details \\
\hline *5 & Identifying key words from previewing test questions and vocabulary lists \\
\hline
\end{tabular}

${ }^{*}$ Strategy stimulated by the support. 
Other strategies such as translating what is heard into Chinese, trying to understand every word, listening for key words, creating a picture of what is heard, and guessing content based on the understood parts were considered general strategies that students would use without being provided with support. However, it was interesting to discover that students' responses to the SWT (strategies while taking tests, see Appendix B) section of the questionnaire were consistent with their interview reports. For example, when examining their use of SWT, we found that translating what is heard into Chinese was ranked 11th among the 18 items. This strategy was neither advantageous nor practical in this type of listening task because students had to listen to a whole passage continuously rather than listening to a short conversation. Short conversations or dialogues contain more fillers, false starts, and pauses, which allow listeners more time to process the input, and thus they may form the habit of translating what they hear. If listeners try to translate what is heard into their mother tongue, they are not likely to be able to match the speed of the speaker and will miss a good deal of information. Therefore, as Vandergrift (1997b) puts it, a successful listener must resist the compulsion to translate the input.

Overall, students' oral reports on strategy use showed that varying types of listening support did affect their strategy use, varying from metacognitive strategies-such as finding content clues from test questions and predicting possible topics- to cognitive strategies like revising comprehension, matching words, and listening selectively. The results also revealed that listening support had more effect on listeners' metacognitive strategies, which helped them predict and plan their listening. According to Vandergrift (1997b), the better a learner's language proficiency, the greater is his or her metacognitive strategy use.

\section{Strategy Use by Anxious/Non-Anxious Learners With Varying Test Tasks}

In the above section we see how strategy use was affected by varied test tasks. In the following section, I analyze the strategies used by anxious and non-anxious students while taking a listening test with varied types of listening support. The strategies used overall by anxious and non-anxious students are presented in Table 7.

Anxious Students' Listening Strategy Use

In the PQ group, previewing test questions apparently affected students' strategy use considerably, as they all reported that after reading the test questions, they found it easier to identify keywords. The three anxious learners agreed unanimously that they chose an answer that they had previously seen if the word found in the test questions matched the word in the recordings. Buck (2001) refers to this as lexical overlap. For example, 
Table 7

A Comparison of Strategy Use in Listening Comprehension Between Anxious and Non-Anxious Learners

\begin{tabular}{|c|c|c|}
\hline & Anxious & Non-Anxious \\
\hline$P Q$ & $\begin{array}{l}\text { - trying to find out key words } \\
\text { choosing the answers by } \\
\text { matching words in the test } \\
\text { questions and hearing }\end{array}$ & $\begin{array}{l}\text { - translating what is being heard into Chinese } \\
\text { - taking notes } \\
\text { - focusing on keywords } \\
\text { - trying to hear every word } \\
\text { - listening for necessary information only }\end{array}$ \\
\hline $\mathrm{RI}$ & $\begin{array}{l}\text { - translating what is heard into } \\
\text { Chinese } \\
\text { - guessing the contents based on } \\
\text { the understood words } \\
\text { - trying to find topic clues from test } \\
\text { questions } \\
\text { - choosing the answers by matching } \\
\text { words in the test questions and } \\
\text { hearing/listening for keywords } \\
\text { - revising comprehension by } \\
\text { listening three times }\end{array}$ & $\begin{array}{l}\text { - creating a picture of what is being heard } \\
\text { - linking what is heard with one's experience } \\
\text { - listening for messages }\end{array}$ \\
\hline TP & $\begin{array}{l}\text { - guessing the content based on the } \\
\text { understood parts } \\
\text { choosing the answers by matching } \\
\text { words in the test questions and } \\
\text { hearing/listening for keywords } \\
\text { - listening for detailed information } \\
\text { because the topics were known }\end{array}$ & $\begin{array}{l}\text { - focusing on the question words in the test } \\
\text { questions } \\
\text { - listening for information relevant to the } \\
\text { questions only } \\
\text { - avoid thinking about the input in Chinese } \\
\text { - telling oneself not to be nervous } \\
\text { - telling oneself not to think about the mark }\end{array}$ \\
\hline VI & $\begin{array}{l}\text { - guessing the content based on the } \\
\text { understood words } \\
\text { - predicting the topics through test } \\
\text { questions and vocabulary lists } \\
\text { - choosing the answers by matching } \\
\text { words in the test questions and } \\
\text { hearing/listening for keywords } \\
\text { - listening for topics first, then details }\end{array}$ & $\begin{array}{l}\text { - identifying key words from previewing test } \\
\text { questions and vocabulary lists } \\
\text { - predicting the topics through test questions } \\
\text { and vocabulary lists }\end{array}$ \\
\hline
\end{tabular}

I tried to hear the keywords. If I heard a word which also appeared in the test questions, then I chose that for the answer. (Christine)

Anxious students in the RI group used more and somewhat different strategies from those used in the PQ group. George reported that listening three times allowed him to revise his comprehension, and he also translated some of the input into Chinese. Helen reported that she guessed the main ideas of the listening passages based on the keywords, but she had her own 
definition of what were keywords; so caution is needed when interpreting her reports. She noted:

Keywords for me were the words that I could understand, not the real important words in the listening passages. If I could find out the real keywords in the recordings, I would not have difficulty understanding the talk.

From Helen's description, her strategy was apparently guessing the content based on known words, not the important words. However, Isabella used the same strategy as those in the PQ group:

I tried to find some clues from the test questions. When the speaker said a word matching the ones that I read on the test paper, I chose that one for the answer.

It was obvious that both previewing questions and listening three times affected their strategy use, and they tended to use bottom-up processing to comprehend the input.

Anxious students in the TP group reported that because they knew the topics and read the test questions before the test, they paid attention directly to the detailed information that was necessary for answering the questions. For example, Tracy expressed the view that

When I previewed the questions, I had an impression of what I read. If I heard something matching what I read, then I chose that answer.

In relation to the strategies used by the students in the VI group, it was discovered that they also used the same strategy as the TP group. They reported that they could guess the topics from the vocabulary lists, which helped with accuracy. For example, Mary reported,

When I listened, I did not have to guess the meanings of those words and I could quickly grasp the topics, and then focus on the details. It saved me spending a lot time guessing blindly and looking for topics.

Guessing seemed to be used most often by these students. According to Nathan's description,

I used the words I could understand to guess the content. You know I couldn't understand most of the parts, so guessing is the best strategy.

If the input was incomprehensible, they guessed the content based on the understood parts. Overall, the main strategies used by anxious students can be summarized as follows:

1. matching the words found in the test questions and heard in the recordings,

2. predicting discourse topics from test questions, 
3. continuing to revise comprehension through repeated input,

4. directly listening for detailed information because the topics were known, and

5. predicting the topics through vocabulary in the lists and test questions.

If the effects of varied types of listening support are excluded, the two most frequently used strategies were guessing the content based on the understood parts and listening for key words (see Appendix B). From this we may conclude that the types of listening support had some influence on anxious students' decisions about strategy use. Overall, anxious students in the PQ and RI groups tended to use more bottom-up processing, implying that these test tasks encouraged greater reliance on linguistic cues. On the other hand, those in the TP and VI groups used a balance of bottom-up and top-down processing strategies.

\section{Non-Anxious Students' Strategy Use}

Moving to the strategies used by non-anxious students, in the PQ group, the three students all used varied strategies, which included translating what they heard into Chinese, taking notes, focusing on key words, listening for necessary information only, and listening hard and trying to understand every word. Debby, whose LP was low, reported,

I roughly translated what I heard into Chinese. I also jotted down some keywords and verb tenses.

Apparently, Debby paid attention to local cues, and she could probably only partly understand the talk. However, Ellen used a totally different strategy:

Because I had already previewed the questions, I knew what I should listen for. When the tape began to run, I focused on the necessary information only.

Frank used a bottom-up strategy:

I tried to understand every word and to find out the keywords. If I heard a word that matched a word in the test question, then I circled it right away.

Non-anxious students in the RI group used two strategies that had not been used by any other students. Jill said,

When I was listening, I created a picture of what I heard. It helped me understand better. When encountering the part I could not understand, I tried to identify keywords or skipped that part.

Jill seemed to use both top-down and bottom-up processing; when the input was comprehensible, she used top-down processing, whereas she used 
a bottom-up strategy when the input was incomprehensible. In support of Jill's strategy use, Kate added,

In addition to creating a picture of the talk, I linked my own experience with what I heard.

Because these two students were at a high level and their strategies were different from those of other students, it is worth examining their listening comprehension scores. Jill scored 93 out of 100 and Kate 80 out of 100. Jill further explained her listening technique,

When I listened, I did not need to understand all the words and phrases; I listen for the messages only.

Their satisfactory performance may suggest that competent learners do not focus on individual words, but listen for the global message.

The opinions of the TP group about the support method were divided. It was apparent that they all used varied strategies. Wilson, who scored 90 out of 100, used selective listening, meaning that he just listened for necessary information. As he put it,

When I previewed the questions, I tried to remember the question words, such as when, where, what, and so on. When I listened, I focused on those questions only.

From this student's report, his strategy use was obviously influenced by question previewing. Another student, Vivian, was concerned about not being distracted by the treatment and test questions. She said,

When I was listening, I tried to think in English, just like I was listening to Chinese.

The non-anxious student Wilbur considered paying attention the most important strategy to use.

I told myself not to worry about the mark, and be attentive to the test.

None of the students reported on how background knowledge affected their strategy use. However, two of the three students reported that when they engaged in topic preparation, their comprehension improved.

The non-anxious students in the VI group reported that they relied a great deal on the words in the lists and in the test questions. Pam reported,

I think that a lot of keywords could be identified through the vocabulary lists and the test questions. After I read those words, I could roughly guess the topic of the talk.

Patricia also reported that she used the words from the lists to predict the topics, which helped her greatly. Without doubt the two students' listening 
strategies were influenced by studying the vocabulary and preview questions. By previewing the vocabulary, the students believed they could roughly guess what the topics would be.

In terms of the quantity of strategies, non-anxious students used many more strategies than anxious ones; in total 13 strategies were identified (see Table 7). These included cognitive strategies—such as trying to hear every word, translating what they heard into their native language, not thinking in Chinese, listening selectively, and associating what they heard with their own experience-and also metacognitive strategies such as predicting the topics through the words found in the test questions and vocabulary lists; and even affective strategies such as not thinking about the mark and suppressing negative thoughts.

Because non-anxious students employed many varied strategies, it is difficult to detect which were used most frequently. However, when input was incomprehensible the non-anxious students used the same strategy: skip that part and keep on listening. As with anxious students, previewing questions seemed to have the most effect across the groups. More students reported that after reading the test questions, they focused only on the relevant information. Overall, three strategies reflected the direct influence of support methods: listening for relevant information and predicting topics and identifying key words through studying the vocabulary and reading the test questions.

\section{Conclusion}

The following is a summary of test-taking strategies, with responses to the research questions.

1. All forms of listening support influenced learners' use of strategy to some extent. Previewing questions made some students more selective and helped them focus on information necessary only for the answers. Before listening, most students tried to predict the topic through the questions, and while listening, many students used lexical overlap, looking for answers by matching the words found in the test questions and heard in the recording. Repeated input offered students the chance to revise their comprehension, assisting learners' strategy use and allowing them time to prompt themselves not to be nervous. With the provision of topical knowledge, students tended to focus on the details because they had been exposed to the global background of the topics. Finally, with vocabulary instruction before the test, students tried to predict the topic or content by using the words in the lists.

2. Strategies reported by anxious students were similar across the four groups. The strategies most frequently mentioned were: matching words found in the test questions and heard in the recordings, predicting discourse topics from test questions, continuing to revise 
comprehension through repeated input, directly listening for detailed information when the topics were known, and predicting the topics through vocabulary in the lists and test questions. In contrast to the anxious group, non-anxious students used many varied strategies, but only three reflected a direct effect from listening support. These were listening for relevant information (with PQ support) and predicting the topic and identifying key words through the vocabulary list and test questions (with TP and VI support).

This study shows that varying forms of listening support have an effect on learners' strategy use. This study also reveals that anxious students use varied strategies compared with non-anxious students. However, looking into the listening anxiety level of students without considering their reasons for being more or less anxious is insufficient to explain the differences in choice of strategies. Therefore, it is important to point out the limitations identified during student interviews. Although earlier research has shown that listening anxiety in general is associated with language competence, this was challenged when our interviews discovered other hidden problems for learners.

During the interviews, students reported why they were anxious or less anxious about English listening. Two major factors can be associated with high levels of listening anxiety: low listening proficiency, causing students to worry about failing; and being overly concerned about their performance, meaning that students wished to achieve higher marks rather than being satisfied with a score of 60 (the pass threshold). Three types of students were found to be less anxious: those who had better listening proficiency, those who considered English listening to have no practical value in their daily life in an EFL environment, and those who acknowledged that English listening was too difficult for them (such students had never passed any tests). These three types of students did not feel the need to be anxious. This could explain why some students reported telling themselves not to be nervous and not to think about their marks. The comments by the latter two types of nonanxious students suggest perhaps that they did not consider what strategies they were going to use according to the varying support offered, but simply finished the test. On the contrary, anxious students seemed to be more serious about the test.

A second limitation of the study is consideration of the learners' listening competence. Without investigating the listening performance of learners with varying levels of anxiety, it proved difficult to discover the subtle differences among students experiencing such levels of anxiety. In this study, only Jill, Kate, and Wilson had high listening proficiency, and their strategies were found to be different from those of other interviewees.

The two limitations mentioned above highlight the need for caution when interpreting the findings. Despite the limitations, based on the overall 
reported strategies, some interesting patterns were found and deserve attention. Before listening, most students regardless of their anxiety levels knew how to make good use of available information to predict the topics and content. However, while listening, excluding the three students mentioned above, most students used guessing to match words read in the test questions and heard in the recording. Their problem was language competence, which may have inhibited them from using the strategies they intended to use. This finding is somewhat comparable to those of the study by Zhang and Goh (2006), which found that their students were generally aware of the usefulness of the strategies, but were not conscious or confident strategy users. By contrast, students with good listening performance were able to screen the information, creating a picture of the topics and linking this with their previous experience. From this finding, we may conclude that most of the students possessed strategic knowledge, meaning that they knew how to use the available information, but most lacked strategic competence to implement their knowledge because of their limited language ability. Therefore, although many students reported that they tried to predict the topics and content of the talk, few could take advantage of their predictions while listening. This was confirmed from their listening comprehension performance. To answer the supplementary research question about closure of the gap between anxious and non-anxious students' performance, the gap was found to relate not to their anxiety levels, but to their listening competence. Hence it is the enhancement of listening proficiency that we should be concerned with rather than the level of listening anxiety.

Finally, in response to the variable results of listening support for a listening test, this study suggests that whether one type of listening support is effective or not depends greatly on whether students know how to use the information provided. This, then, depends on their knowledge of strategies, and whether they can use these depends on their language knowledge and strategic competence. If learners do not know how to use the information available or are unable to apply it, the effectiveness of a particular activity or support will be reduced (Chang \& Read, 2007): it would be the equivalent of offering no listening support. This might have a practical implication for teaching and testing in the foreign-language classroom. If listening support is to be included in a test, then language teachers must ensure that their students know how to use this information and are able to use this support rather than potentially providing much support and still having disappointing results.

This research addresses some of the strategies used by students with varying levels of listening anxiety undergoing varied test tasks. It contributes to an area that has so far received little attention. In this study, only four forms of listening support were investigated and only multiple-choice format was used, but many other forms of support and test methods need to be 
explored. Looking into the strategies used by learners in varied test tasks may help language teachers understand whether a wrong answer is due to a lack of comprehension or a lack of strategic knowledge or competence. With answers to these questions, language teachers will be able to help their students learn more effectively.

\section{Note}

Students' reports quoted in this article are the researcher's translation of what the student said in Chinese.

\section{The Author}

Anna Ching-Shyang Chang is an associate professor in the Department of Applied English at Hsing-Wu College, Taipei, Taiwan, where she teaches English listening, pronunciation, and vocabulary. Her research interests include the development of L2 listening, listening assessment, and vocabulary acquisition.

\section{References}

Aneiro, S. (1989). The influence of receiver apprehension in foreign language learners on listening comprehension among Puerto Rican college students. Unpublished doctoral dissertation, New York University.

Bachman, L.F., \& Palmer, A.S. (1996). Language testing in practice: Designing and developing useful language tests. Oxford, UK: Oxford University Press.

Bacon, S.M. (1992). Authentic listening in Spanish: How learners adjust their strategies to the difficulty of the input. Hispania, 75, 398-412.

Berne, J.E. (1995). How does varying pre-listening activities affect second language listening comprehension? Hispania, 78, 316-329.

Buck, G. (1991). The test of listening comprehension: An introspective study. Language Testing, $8,67-91$.

Buck, G. (2001). Assessing listening. Cambridge, UK: Cambridge University Press.

Cervantes, R., \& Gainer, G. (1992). The effects of syntactic simplification and repetition on listening comprehension. TESOL Quarterly, 26, 767-770.

Chang, C-S. (1999). The effect of repeated listening on different levels of ESL learners. In Proceedings of the first conference on applied English teaching (pp. 72-80). Taipei: Ming-Chuan University.

Chang, C-S. (2004). The effects of anxiety and listening support on listening comprehension in a foreign language classroom. Unpublished doctoral dissertation, Victoria University of Wellington, New Zealand.

Chang, C-S. (2005a). The effects of test task characteristics on English listening comprehension and test-takers' perceptions. Journal of Hsing-Wu College, 29, 29-64.

Chang, C-S. (2005b). How does listening anxiety affect the strategy use of Chinese students studying overseas? Proceedings of 2005 international conference and workshop on TEFL and applied linguistics (pp. 1-11). Taipei, Taiwan: Crane.

Chang, C-S. (2006)Thresholds of background knowledge effect on L2 listening comprehension. Selected papers from the fifteenth international symposium on English teaching (pp. 164-173). Taipei, Taiwan: Crane.

Chang, C-S. (2008). Sources of listening anxiety in learning English as a foreign language. Perceptual and Motor Skills, 106(1), 21-34.

Chang, C-S., \& Read, J. (2006). The effects of listening support on the listening performance of EFL learners. TESOL Quarterly, 40, 375-397. 
Chang, C-S., \& Read, J. (2007). Support for foreign language listeners: Its effectiveness and limitations. RELC Journal, 38, 375-394.

Chaudron, C. (1983). Simplification of input: Topic and reinstatement and their effects on L2 learners' recognition and recall. TESOL Quarterly, 17, 437-458.

Chao, Y-G., \& Chin, L.-Y. (2005) College English majors' listening strategies and difficulties while taking TOEFL. Selected papers from the 14th International symposium on English teaching (pp. 292-301). Taipei, Taiwan: Crane.

Chen, T.Y., \& Chang, G.B. (2004). The relationship between foreign language anxiety and learning difficulties. Foreign Language Annals, 37, 279-289.

Chiang, C.S., \& Dunkel, P. (1992). The effect of speech modification, prior knowledge and listening proficiency on EFL lecture learning. TESOL Quarterly, 26, 345-374.

Chien, C.N., \& Li, W. (1998). The strategy use in listening comprehension for EFL learners in Taiwan. RELC Journal, 29, 66-91.

Cohen, A.D. (1984). On taking language tests: What the students report. Language Testing, 1 , $70-81$.

Conrad, L. (1985). Semantic versus syntactic cues in listening comprehension. Studies in Second Language Acquisition, 7(1), 59-71.

Elkhafaifi, H. (2005a). Listening comprehension and anxiety in the Arabic language classroom. Modern Language Journal, 89, 206-220.

Elkhafaifi, H. (2005b) The effect of prelistening activities on listening comprehension in Arabic learners. Foreign Language Annals, 38, 505-513.

Field, J. (1998). Skills and strategies: Towards a new methodology for listening. ELT Journal, 52, 110-118.

Foley, B.H. (1994). Listen to me: Beginning listening, speaking and pronunciation (2nd ed.). Boston, MA: Heinle \& Heinle.

Goh, C. (2002). Exploring listening comprehension tactics and their interaction patterns. System, 30, 185-206.

Goh, C., \& Taib, Y. (2006). Metacognitive instruction in listening for young learners. ELT Journal, 60, 222-232.

Harsch, K., \& Wolfe-Quintero, K. (2001). Impact listening 3. Hong Kong: Longman.

Hatch, E. (1983). Psycholinguistics: A second language perspective. Rowley, MA: Newbury House.

Hsieh, L.T. (1999). The effects of pre-reading vocabulary instruction and cultural background knowledge activation on Chinese junior college fourth-year students' EFL reading. Proceedings of the sixteenth conference on English teaching and learning in the Republic of China (pp. 227-239). Taipei, Taiwan: Crane.

Huang, J. (2005). Challenges of academic listening in English: Reports by Chinese students. College Student Journal, 39, 553-569.

Hudson, T. (1982). The effects of induced schemata on the "short circuit" in L2 reading Non-decoding factors in L2 reading performance. Language Learning, 32(1), 1-31.

Jensen, C., \& Hansen, C. (1995). The effect of prior knowledge on EAP listening-test performance. Language Testing, 12, 99-119.

Kim, S. (2006) Academic oral communication needs of East Asian international graduate students in non-science and non-engineering fields. English for Specific Purposes, 25, 479-489.

Liu, M. (2006) Anxiety in Chinese EFL students at different proficiency levels. System, 34, 301-316.

Markham, P., \& Latham, M. (1987). The influence of religion-specific background knowledge on the listening comprehension of adult second-language students. Language Learning, 37(2), 157-170.

Mendelsohn, D. (1994). Learning to listen: A strategy-based approach for the second language learner. San Diego, CA: Dominie Press.

Mendelsohn, D. (1998). Teaching listening. Annual Review of Applied Linguistics, 18, 81- 101. 
Mills, N., Pajares, F., \& Herron, C. (2006). A reevaluation of the role of anxiety: Self-efficacy, anxiety, and their relation to reading and listening proficiency. Foreign Language Annals, 39 , 276-295.

Murphy, J.M. (1987). The listening strategies of English as a second language college students. Research and Teaching in Developmental Education, 4(1), 27-46.

Rost, M., \& Ross, S. (1991). Learner use of strategies in interaction: Typology and teachability. Language Learning, 41(2), 235-273.

Sherman, J. (1997). The effect of question preview in listening comprehension tests. Language Testing, 14, 185-213.

Shohamy, E., \& Inbar, O. (1991). Validation of listening comprehension tests: the effect of text and question type. Language Testing, 8, 23-40.

Taglieber, L.K., Johnson, L.L., \& Yarbrough, D.B. (1988). Effects of prereading activities on EFL reading by Brazilian college students. TESOL Quarterly, 22, 455-472.

Teng, H.C. (1993). Effects of culture-specific knowledge and visual cues on Chinese EFL students' listening comprehension. Unpublished doctoral dissertation, University of Minnesota.

Teng, H.C. (1998). The effects of text types and task types on English listening comprehension. English Teaching and Learning, 23, 5-18. [in Chinese]

Thompson, I., \& Rubin, J. (1996). Can strategy instruction improve listening comprehension? Foreign Language Annals, 29, 331-342.

Underwood, M. (1989). Teaching listening. London: Longman.

Ur, P. (1984). Teaching listening comprehension. Cambridge, UK: Cambridge University Press.

Vandergrift, L. (1997a). The Cinderella of communication strategies: Reception strategies in interactive listening. Modern Language Journal, 81, 494-505.

Vandergrift, L. (1997b). The comprehension strategies of second language (French) listeners: A descriptive study. Foreign Language Annals, 30, 387-409.

Vandergrift, L. (1999). Facilitating second language listening comprehension: Acquiring successful strategies. ELT Journal, 53(3), 168-176.

Vogely, A. (1995). Perceived strategy use during performance on three authentic listening comprehension tasks. Modern Language Journal, 79, 41-56.

Weir, C. (1993). Understanding and developing language tests. Hemel Hempstead, UK: Prentice-Hall

Zhang, D., \& Goh, C. (2006). Strategy knowledge and perceived strategy use: Singaporean students' awareness of listening and speaking strategies. Language Awareness, 15(3), 199-219.

Appendix A General Strategies Used Before Taking a Listening Test

\begin{tabular}{|c|c|c|c|c|c|c|c|c|c|}
\hline \multirow[t]{2}{*}{ Item } & \multirow{2}{*}{$\begin{array}{l}\text { Content } \\
(N=160)\end{array}$} & \multicolumn{5}{|c|}{ Frequency of Rating } & \multirow[t]{2}{*}{$M$} & \multirow[t]{2}{*}{$S D$} & \multirow{2}{*}{$\begin{array}{l}\text { Rank } \\
\text { Order }\end{array}$} \\
\hline & & 1 & 2 & 3 & 4 & 5 & & & \\
\hline \multicolumn{2}{|c|}{4 Try my best to do preparation } & 1 & 29 & 35 & 50 & 45 & 3.68 & 1.09 & 1 \\
\hline \multirow{4}{*}{\multicolumn{2}{|c|}{$\begin{array}{l}2 \text { Predict possible test questions } \\
3 \text { Prepare myself in advance to } \\
\text { pay full attention } \\
1 \text { Think about the purpose of }\end{array}$}} & 14 & 36 & 46 & 40 & 24 & 3.15 & 1.19 & 2 \\
\hline & & & & & & & & & \\
\hline & & 9 & 53 & 44 & 43 & 11 & 2.96 & 1.05 & 3 \\
\hline & & & & & & & & & \\
\hline \multicolumn{2}{|c|}{ a test } & 11 & 65 & 42 & 35 & 7 & 2.76 & 1.01 & 4 \\
\hline \multicolumn{2}{|c|}{5 Tell myself I can do well } & 98 & 36 & 14 & 9 & 3 & 1.64 & .99 & 5 \\
\hline
\end{tabular}

Note. $1=$ never, 2 =sometimes, $3=$ often, $4=$ usually, $5=$ =always. 
Appendix B Strategies Used While Taking a Listening Test

\begin{tabular}{|c|c|c|c|c|c|c|c|c|c|}
\hline \multirow[t]{2}{*}{ Item } & \multirow[t]{2}{*}{ Content } & \multicolumn{4}{|c|}{$\begin{array}{l}\text { Frequency of Rating } \\
(N=160)\end{array}$} & \multirow[b]{2}{*}{5} & \multirow[t]{2}{*}{$M$} & \multirow[t]{2}{*}{$S D$} & \multirow[t]{2}{*}{$\begin{array}{l}\text { Rank } \\
\text { Order }\end{array}$} \\
\hline & & 1 & 2 & 3 & 4 & & & & \\
\hline 9 & Guess by context clues & 2 & 16 & 40 & 53 & 49 & 3.82 & 1.02 & 1 \\
\hline 8 & Guess by known words & 9 & 53 & 44 & 43 & 11 & 3.79 & 1.04 & 2 \\
\hline 6 & Try to hear every word & 5 & 20 & 48 & 42 & 45 & 3.64 & 1.11 & 3 \\
\hline \multirow[t]{2}{*}{14} & Link hearing with previous & & & & & & & & \\
\hline & experience & 9 & 30 & 50 & 47 & 24 & 3.29 & 1.11 & 4 \\
\hline 13 & Give up unknown parts & 13 & 32 & 43 & 47 & 25 & 3.24 & 1.18 & 5 \\
\hline 18 & Use titles to predict the content & 5 & 37 & 50 & 52 & 16 & 3.23 & 1.02 & 6 \\
\hline 21 & Monitor attention & 10 & 37 & 52 & 33 & 28 & 3.20 & 1.16 & 7 \\
\hline \multirow[t]{2}{*}{11} & Pay more attention to repeated & & & & & & & & \\
\hline & words & 10 & 36 & 49 & 48 & 17 & 3.16 & 1.09 & 8 \\
\hline \multirow[t]{2}{*}{7} & Listen for the global message & & & & & & & & \\
\hline & only & 10 & 41 & 47 & 38 & 24 & 3.16 & 1.15 & 9 \\
\hline 19 & Listen for topics first & 7 & 42 & 52 & 43 & 16 & 3.12 & 1.05 & 10 \\
\hline \multirow[t]{2}{*}{16} & Translate what is heard into & & & & & & & & \\
\hline & Chinese & 17 & 45 & 39 & 35 & 24 & 3.03 & 1.24 & 11 \\
\hline 10 & Pay attention to pronunciation & 20 & 60 & 41 & 25 & 14 & 2.71 & 1.14 & 12 \\
\hline 22 & Try to be calm & 29 & 51 & 42 & 19 & 19 & 2.68 & 1.24 & 13 \\
\hline 20 & Repeat words mentally & 35 & 55 & 29 & 30 & 11 & 2.54 & 1.22 & 14 \\
\hline \multirow[t]{2}{*}{15} & Imagine a picture of the & & & & & & & & \\
\hline & content & 45 & 54 & 24 & 25 & 12 & 2.41 & 1.26 & 15 \\
\hline 17 & Take notes & 33 & 77 & 24 & 21 & 5 & 2.30 & 1.04 & 16 \\
\hline 12 & Listen for grammar & 60 & 69 & 20 & 6 & 5 & 1.92 & .97 & 17 \\
\hline 23 & Close eyes and concentrate & 94 & 37 & 16 & 11 & 2 & 1.69 & .99 & 18 \\
\hline
\end{tabular}

Note. $1=$ never, 2=sometimes, $3=$ often, 4=usually, 5=always.

\section{Appendix C}

English Listening Strategies Questionnaire

This is a questionnaire on English listening strategy use especially designed for speakers of other languages learning English. You will find statements about strategy use when you listen to English in different situations. There are no right or wrong, good or bad answers to these statements. Please answer in terms of how well the statement describes you. Do not answer what other people think you should do. Before you answer the statements, please read the definitions of listening strategy scales first.

5: ALWAYS means that the statement is true of you almost always.

4: USUALLY means that the statement is true more than half of the time.

3: OFTEN means that the statement is true about half of the time.

2: SOMETIMES means that the statement is true less than half of the time.

1: NEVER means that the statement is never true of me.

A BEFORE TAKING AN ENGLISH LISTENING TEST

1. Before taking an English listening test, I think about the purpose of the test and then choose strategies to manage it. 
2. If I know the content that will be tested, I try to think of possible questions that I will have to answer.

3. I prepare myself in advance to pay full attention to the tasks.

4. Even though I don't know what will be tested, I will do my best to do the preparation, e.g., Doing more listening practice, memorizing more words.

5. I tell myself that I am a good listener and I can do well on my listening tasks.

B WHILE TAKING AN ENGLISH LISTENING TEST

6. I try to hear every word clearly.

7. I focus on the message (main ideas and key words), not every word.

8. I fill the gaps by guessing based on words and phrases I understand.

9. I guess the meaning of unknown words by using context clues, such as the situation (e.g., a supermarket) and relationship between speakers (e.g., a salesperson and a customer).

10. I pay more attention to pronunciation, e.g., stressed words, and the variation of intonation.

11. I pay particular attention to repeated words.

12. I listen for grammatical structures, for example, the verb tenses, the passive voice, etc

13. I give up on the words I don't understand or miss so I can keep up with the speaker.

14. I link what I know and my previous experience with what I hear.

15. I imagine a picture of the context to comprehend texts.

16. I have to mentally translate what I hear into Chinese, so I can understand what the speaker says.

17. I take notes.

18. I use the title to predict what the speaker would say and listen to confirm my prediction.

19. I listen for topic, then details.

20. I repeat words or phrases softly or mentally.

21. I monitor my attention. If I am absent-minded, I will refocus immediately.

22. I try to relax myself, and keep telling myself it is useless to be anxious.

23. I like closing my eyes and listening.

\section{Appendix D}

\section{Post-Listening Interview Guidelines}

The interviewees were categorized into anxious and less anxious (nonanxious) groups. The questions were as follows.

1. What do you think of this type of listening? (difficult, challenging, easy? Please offer the reasons).

2. How do you like this type of listening test? (like or dislike it, and why?)

3. Were you anxious before you took the test? (if yes, then why? If no, then why not?)

4. When did you start to prepare for the test?

5. What preparations did you do before you came to the test?

6. Since we have finished the test, how do you feel now?

7. In what situations do you feel anxious? For example, when you watch English TV programs, listen to English songs, or take English listening tests.

8. What do you think to be your major source of English listening anxiety? (for the anxious group)

9. Since you said you are anxious about English listening, could you tell me more specifically about your anxiety? For example, do you think the anxiety may help you be more attentive, or do you think the anxiety made you forget the content that you prepared for the test? (for the anxious group).

10. Since you said that you are more relaxed than other students, could you tell me why you are not anxious about English listening? (for the less anxious group).

11. Since you reported that you are/aren't anxious while listening to English, could you tell me how you took the test just now. For example: 
a. Did you have to translate what you heard into Chinese?

Could you tell the keywords, or the main sentences?

d. Did you take notes?

e. What did you do when you heard an unknown word?

f. Did you guess a lot of answers?

g. Did you continue listening when you heard the words or phrases that seemed quite unfamiliar to you?

h. Did you pay full attention to the listening?

i. What were the major difficulties for you in understanding the listening passages, for example: speed, accent, topic, unfamiliar words, long sentences, and overloading the memory?

\section{Master's Program in TESL}

Mount Saint Vincent University, in co-operation with Saint Mary's University, offers the Master of Education in Curriculum Studies: TESL program. Students can complete the full-time degree in eight months, or on a part-time basis.

Program information and admission requirements are available online at www.msvu.ca/education under Curriculum Studies.

Applications are available online at www.msvu.ca/apply_online.

For more information, please contact Jocelyne Lavoie at jocelyne.lavoie@msvu.ca or toll-free at 1-877-433-2889.

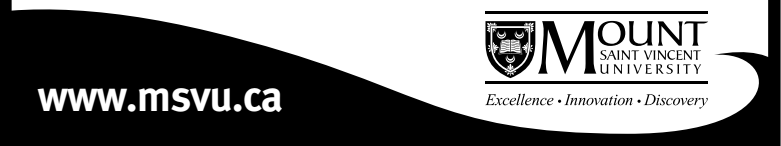

